\title{
SUBSISTING COPYRIGHTS AND INNOCENT INFRINGEMENT
}

United States copyright law gives to the author of a literary work the exclusive right to publish or reproduce his work in any communication medium. ${ }^{\text {I }}$ In order to acquire and maintain this monopolistic right, each reproduction of the copyrighted material must contain notice of copyright in the proper form and affixed in the proper place. $^{2}$ The notice requirement is designed to warn would-be infringers that the work is protected, ${ }^{3}$ as well as to differentiate between those works which may be copied freely and those which can be reproduced only with the author's permission. ${ }^{4}$ Publication without the notice or with it but in a defective form can result in forfeiture of the copyright and thus thrust the work into the public domain. ${ }^{5}$

The notice requirement presents special problems to the copyright proprietor since maximum commercial exploitation of a copyrighted work may require several editions or the production of other versions in different communication media. Thus a novel may be serialized in a magazine, printed in several hardback and paperback editions and dramatized on the stage and in motion pictures before it finally appears as a late movie on television. Though the owner of the original copyright has the right to republish his work and to create and exploit other versions, he will often license or sell the right to exploit these commercial opportunities. Each of these later editions or adaptations of the original work to a different communication medium-termed "derivative works" B - necessarily includes some or all of the copyrighted elements of the original work. Just as reissuing a work in the

\section{U.S.C. \$ 1 (1964).}

217 U.S.C. $\$ 10$ (1964).

3 H. M. Kolbe Co. v. Armgus Textile Co., 315 F.2d 70 (2d Cir. 1963) ; Shapiro, Bernstein \& Co. v. Jerry Vogel Music Co., 161 F.2d 406 (2d Cir. 1946), cert. denied, 331 U.S. 820 (1947).

4 Some authors, notably in academic and scientific circles, prefer publishing their works without copyright to promote dissemination of their ideas. This intentional waiver of the copyright privilege is considered a "dedication" of the work to the public domain, as distinguished from an involuntary forfeiture of copyright through failure to meet the statutory requirements. See National Comics Publications, Inc. v. Fawcett Publications, 191 F.2d 594, 597-98 (2d Cir. 1951) (L. Hand, J.), opinion clarified, 198 F.2d 927 (2d Cir. 1952).

5 See, e.g., Public Affairs Associates v. Rickover, 284 F.2d 262, 269-71 (D.C. Cir. 1960), vacated per curiam on other grounds, 369 U.S. 111 (1962); Klasmer v. Baltimore Football, Inc., 200 F. Supp. 255 (D. Md. 1961).

"A "derivative work" is one, based in whole or in substantial part upon a prior or "underlying work," which satisfies the requirement of originality and is not itself an infringing work. NIMMER, CopYRIGHT \$39 (1965). Compare H.R. 4347, 89th Cong., 1st Sess. $\$ 101$ (1965). 
same form as the original work constitutes a publication of that work, ${ }^{7}$ every derivative work, to the extent that it incorporates material from the original work, is a publication of the original copyrighted material. ${ }^{8}$

The owner of a subsisting copyright ${ }^{9}$ faces particular problems in the event that the copyright notice on the derivative work is defective or omitted. Does publication of previously copyrighted material in a defectively copyrighted derivative work result in forfeiture of the subsisting copyright? This question has not been extensively litigated, and the decisions in the cases which have raised the issue are not wholly consistent. In Bentley $v$. Tibbals, ${ }^{10}$ the plaintiff copyrighted his work in England and the United States. He subsequently published a new United States edition which included all the old material and a substantial amount of new matter which he failed to copyright. Defendant acquired a copy of the second edition and reprinted it without the author's permission. The court held that the plaintiff could not enjoin the copying of the second edition even though it contained a legend that parts of the work had been copyrighted previously. The stated rationale for the Bentley decision was that "one who so embodies copyrighted with uncopyrighted matter that one reading his work cannot distinguish between the two has no right to complain if the book is republished by third parties." 11 The court did not purport to decide that the plaintiff had lost his copyright on the first edition, but rather that he could not enjoin copying of the second edition. Resolution of the first question would have been necessary only if the defendant in Bentley had copied solely from the first edition. However, to hold a copier liable under these facts while finding no infringement in Bentley would produce the anomalous result that the author's right to enjoin the reproduction of his work depends upon the source from which it is copied. In effect, the court's decision in Bentley deprived the author of his right to the monopolistic exploitation of his work as fully as if it had expressly held the subsisting copyright to have been forfeited.

The question was again presented in Sieff $v$. Continental Auto Supply, Inc. ${ }^{12}$ The plaintiff had published a series of catalogues; new material in Numbers 470 and 471 was copyrighted and included in Number 472 , which was uncopyrighted. Plaintiff contended that the "publication of No. 472 without copyright notice 'did not affect the

7 See 17 U.S.C. \& 10 (1964) ; Deward \& Rich, Inc. v. Bristol Sav. \& Loan Corp., 120 F.2d 537, 540 (4th Cir. 1941).

8 NIMMER, op. cit. supra note $6, \S 57.1$.

9 A subsisting copyright is a copyright on the preexisting material (old matter) which is used in a derivative work. The derivative copyright covers only the new matter added by the author of the derivative work.

10223 Fed. 247 (2d Cir. 1915).

$11 \mathrm{Id}$. at 256.

1239 F. Supp. 683 (D. Minn. 1941). 
force or validity of the subsisting copyright . . . ."13 Defendant countered with the argument that the validity of the subsisting copyright on the material previously copyrighted could not be maintained without notice of copyright. The court agreed and granted summary judgment for the defendant even though the plaintiff insisted that it did not intend to abandon the copyright. ${ }^{14}$ Thus, it appears that the incorporation of previously copyrighted material into a derivative work must be indicated by an appropriate notice of copyright if the derivative work is not separately copyrighted. Failure to do so may result in forfeiture of the subsisting copyright.

The most recent case raising the issue, Grove Press, Inc. v. Greenleaf Publishing Co., ${ }^{15}$ reached an apparently contrary result. The author, Jean Genet, copyrighted a French language edition of his work in France in 1949, thus obtaining copyright protection in the United States under a then existing treaty. ${ }^{16}$ In 1954 he authorized an English translation of the work which, the court assumed arguendo, ${ }^{17}$ was not copyrighted in the United States. Defendant obtained this translation and copied it. In an infringement suit he contended that the transiation, which was produced with the consent of the author, necessarily included the novel, and that the novel as translated was automatically thrust into the public domain since it was not copyrighted in this country. ${ }^{18}$ The court rejected this claim and held that the copying of an uncopyrighted translation infringed the original 1949 copyright. The rationale was that the defendant copied not only the words of the translation but also the plot, characters and dialogue of the original work, thus infringing the subsisting copyright. ${ }^{19}$

The Grove Press court also developed a second rationale. While conceding that the translation was in the public domain, the court stated that the failure of the translator to obtain copyright protection for his work would not be fatal to the subsisting copyright unless the author consented to such dedication. ${ }^{20}$ The court then examined the

$13 I d$. at 686 .

14 Ibid.

15247 F. Supp. 518 (E.D.N.Y. 1965).

16 See 17 U.S.C. $\$ \$ 9$ (b)-(c) (1964) for the text of the statutory provisions concerning treaties. The present copyright treaty between the United States and France is the Uniform Copyright Convention, which is reproduced at 17 U.S.C. $\S 9$ (c) (1964).

17 Grove Press, Inc. v. Greenleaf Publishing Co., 247 F. Supp. 518, 523 n.6 (E.D.N.Y. 1965).

$18 \mathrm{Id}$. at 524 . In 1952 five pages of the translation were published for the first time in a copyrighted anthology. Plaintiff contended that the copyright on these five pages was incorporated into and protected the full translation when it was published without copyright. The court had denied equitable relief based upon this claim in an earlier opinion. Grove Press, Inc. v. Greenleaf Publishing Co., 247 F. Supp. 127 (E.D.N.Y. 1965).

10247 F. Supp. at 524-25.

20 Id. at 527. 
contract between the author and the translator and noted that it did not permit the translator to sell the work in the United States or England, and that each copy was required to carry a notice to that effect. These contract provisions, the court concluded, indicated that the author did not intend to abandon his work to the public, and that the legend in each copy was a sufficient indication of the existence of a subsisting copyright. ${ }^{21}$

Grove Press seems indistinguishable from both Bentley and Sieff, for these cases all involved previously copyrighted material subsequently published in an uncopyrighted derivative work; yet Grove Press reached a result arguably contrary to the other cases. These cases may be reconciled on the basis of the nature of the copyrighted material incorporated into the uncopyrighted derivative work. Both Bentley and Sieff involved the incorporation of copyrighted material into a larger uncopyrighted work, ${ }^{22}$ in such a way that it would be impossible for a reader to determine which portions had been copyrighted previously. Since one purpose of the copyright law is to discriminate between works which may be copied freely and those which are protected, ${ }^{23}$ these cases may stand for the proposition that one who incorporates copyrighted material into a larger uncopyrighted work so that the two are indistinguishable will be held to have forfeited the copyright on the incorporated material. This rationale avoids placing on the copier the burden of sorting the copyrighted "wheat" from the uncopyrighted "chaff." Viewed in this light, Bentley and Sieff are reconcilable with Grove Press for in the latter case the copier was warned that the derivative work followed

21 Id. at 527-28. The legend stated:

Publishing in agreement with the Librairie Gallimard.

The present translation follows the original and only complete text, though it incorporates a few footnotes which the author added to the later edition.

Copyright 1954 by B. Frechtman and The Olympia Press, Paris. On the back cover the translation carried the notation "Not to be sold in the U.S.A. or U.K." Id. at 521 . The court in a prior opinion indicated that this notation may have been "intended as the semantic equivalent of the then widely-sought-for literary accolade, "Banned in Boston." Grove Press, Inc. v. Greenleaf Publishing Co., 247 F. Supp. 127, 133 n.9 (E.D.N.Y. 1965).

In Bentley the derivative work also contained warning, perhaps even more explicit, of the presence of a subsisting copyright. The legend proclaimed: "This Code includes the Telegraph Cyphers entered according to act of Congress in the year 1906, by E. I. Bentley in the office of the Librarian of Congress at Washington, D.C. A11 rights reserved. Entered at Stationer's Hall." Bentley v. Tibbals, 223 Fed. 247, 250 (2d Cir. 1915). Yet this warning was not sufficient to permit plaintiff to enjoin defendant's copying.

22 In Bertley, the second edition was a revised and enlarged version of the first work. 223 Fed. at 250 . Sieff involved only some one hundred copyrighted items in the catalogue. $39 \mathrm{~F}$. Supp. at 685.

23 See text accompanying note 4 supra. 
the original French novel, which was protected by a copyright. ${ }^{24}$ Hence, there was no real mixing of copyrighted with uncopyrighted material, and the subsisting copyright was not forfeited.

Reconciling the cases on this basis, however, raises a question as to the correctness of the Grove Press decision. If copying the translation infringed the copyright on the original French novel, it must be because the translation is "substantially similar to" the original copyrighted work..$^{25}$ The question remains whether publication of the translation without notice causes a forfeiture of the subsisting copyright. $^{26}$ Obviously, a translation is not a copy in the literal sense of the word since it contains the original work of the translator. This new matter contributed by the translator may be separately copyrighted. ${ }^{27}$ Hence it may be argued that since the translator could only copyright the new matter he contributed, the failure to copyright it could cause the forfeiture of only the new matter, leaving the old matter protected by the subsisting copyright. ${ }^{28}$ This approach, however, emphasizes form over substance, for the very purpose of a translation is to take what has been expressed in one language and transfer it to another, while preserving the original author's style and artistry. Only the word forms change, while what is being expressed-the plot, the theme and the development of the characters-remains the same. In this essential respect a translation is a copy of the original even though it contains the effort of the translator. Holding that publication of an uncopyrighted translation does not forfeit the subsisting copyright extends copyright protection to the new matter in the translation, for it is impossible to copy the words of the translation without copying the format and other copyrighted elements of the derivative work. Thus, the translation is protected from infringement even though it is uncopyrighted. This approach also places a heavy burden on copiers, for omission of the copyright notice makes it difficult accurately to determine if parts of a work are protected by a copyright. ${ }^{29}$ It is therefore possible for a copier unknowingly to expose himself to heavy penalties for an innocent infringement of a subsisting copyright. Moreover, in this situation the owner of the subsisting copyright is able to protect himself, by requiring the derivative owner either to copyright his work or to indemnify in the event of forfeiture or

24 There was also a legend indicating a subsisting copyright in Bentley, see note 21 supra, but unlike Grove Press, large parts of the second edition in Bentley could be copied without taking material that had been previously copyrighted.

25 See NIMMIER, op. cit. supra note $6, \$ 143$.

26 See generally $i d$. $\$ \S 82-88$.

2717 U.S.C. $\$ 7$ (1964).

28 See G. Ricordi \& Co. v. Paramount Pictures, Inc., 189 F.2d 469 (2d Cir.), cert. dentied, 342 U.S. 849 (1951).

29 This problem of distinguishing between the copyrighted and the uncopyrighted material may explain the Bentley and Sieff cases. See text accompanying notes $22-24$ sippra. 
infringement of the subsisting copyright. ${ }^{30}$ There are therefore cogent arguments for holding that the publication of an uncopyrighted derivative work which is substantially similar to the subsisting work should forfeit the subsisting copyright.

Both a determination that the subsisting copyright is forfeited and the Grove Press rationale have undesirable consequences. In the first situation a subsisting copyright owner may lose all copyright protection through the negligence of his licensee. Since the work may be produced in several different media at the same time, the possibility of error by any one licensee is increased. Furthermore, the subsisting copyright proprietor would have only one remedy-breach of contract-and the computation of damages may be highly speculative. The copyright proprietor therefore might not be fully compensated for the loss of his copyright. On the other hand, the Grove Press rationale exposes an innocent infringer to the possibility of unknowingly infringing a subsisting copyright, as well as extending copyright protection to a derivative work even though it is uncopyrighted.

A third alternative eliminates many of the undesirable consequences of both the Sieff and Grove Press resolutions. Section 21 of the copyright statute ${ }^{31}$ provides that accidental omission of notice of copyright from a particular copy or copies will not forfeit the copyright if the owner has attempted to comply with statutory requirements, but it will prevent recovery of damages from an innocent infringer who was misled by the omission of notice. A permanent injunction will not be granted, however, unless the innocent infringer is reimbursed for his reasonable out-of-pocket expenses. Section 21 preserves the copyright without exposing the innocent copier to heavy penalties for infringement. However, the section is of limited applicability for it applies only when there has been an accidental omission of notice from a small number of copies, and it does not speak directly to the problem of innocent infringement of subsisting copyrights.

The approach of section 21 has been adopted and expanded by the congressional committee which is contemplating revision of present copyright law. Section 404 (a) of the proposed revision ${ }^{32}$ provides that the omission of notice of copyright from a copyrighted work will not invalidate the copyright if the work is registered ${ }^{33}$ within five years

30 See National Comics Publications, Inc. v. Fawcett Publications, Inc., 191 F.2d 594, 600-01 (2d Cir. 1951) (L. Hand, J.), opinion clarified, 198 F.2d 927 (2d Cir. 1952) ; American Press Ass'n v. Daily Story Publishing Co., 120 Fed. 766, 768-69 (7th Cir. 1902), appeal dismissed, 193 U.S. 675 (1903). See also Hower,, CoPYRIGHT LAW 71 (rev. ed. Latman 1962).

3117 U.S.C. $\$ 21$ (1964).

32 H.R. 4347, 89th Cong., 1st Sess. § 404(a) (1965).

33 Under the proposed statute, as under the present law, a copyright proprietor must inform the Copyright Office that he is claiming copyright protection for certain published material. No suit for infringement can be brought until the work is 
after its initial publication and the copyright proprietor makes a reasonable effort to add notice to all copies after the omission is discovered. Since the absence of notice will not automatically place the work in the public domain, section 404 (b) ${ }^{34}$ provides for a limitation of remedies in cases of innocent infringement without notice of copyright. If an infringer is misled by the omission of notice, he will be liable only for the statutory damages contained in section 504(c)..$^{35}$ And if the infringement occurs before the work is registered, the copyright proprietor is precluded from recovering statutory damages unless the work is registered within three months after its first publication. ${ }^{36}$ Thus in most cases the sole remedy for innocent infringement is an injunction. If the injunction is granted, the copyright proprietor may be required to reimburse the infringer for the latter's reasonable expenses. Or the court may deny the injunction and require the copyright proprietor to license the copier to produce the infringing work, but at a reasonable royalty. ${ }^{37}$ The proposed revision liberalizes the notice requirement and provides a more flexible statutory scheme for fashioning remedies against innocent infringers. If enacted, the statute would give copyright proprietors in situations like Bentley and Sieff the opportunity to register their works within five years, and thus rectify the original omission of notice.

The revision leaves unanswered the crucial question whether, and to what extent, the subsisting copyright is impaired by failure of the derivative owner to fulfill notice and registration requirements. This question can be answered by balancing the two competing interests of copyright law-protecting the copyright proprietor's monopoly and

registered. H.R. 4347, 89th Cong., 1st Sess. $\$ \$ 407-11$ (1965). See also 17 U.S.C. $\$ \$ 11$, 13 (1964). Notice of copyright must be placed on the published material to warn copiers that the work is protected, and notice is a separate requirement from registration. See H.R. 4347, 89th Cong., 1st Sess. \$ 401 (1965). See also 17 U.S.C. \$ 10 (1964). 34 H.R. 4347, 89th Cong., 1st Sess. \$404(b) (1965).

35 H.R. 4347, 89th Cong., 1st Sess. $\$ 504$ (c) (1965). Section 504(a) provides: Except as otherwise provided by this title, an infringer of copyright is liable for either: (1) the copyright owner's actual damages and any additional profits of the infringer, as provided by section (b) ; or (2) statutory damages, as provided by section (c).

Section 404(b) creates an exception to that rule:

Any person who innocently begins an undertaking that infringes a copyright incurs no liability for damages or profits under section 504 if he proves that he was misled by the omission of notice . . .

If the word "damages" in $\S 404(\mathrm{~b})$ is construed to include actual damages and statutory damages, as defined in $\$ 504$ (c), then an innocent infringer will incur no liability. However, it appears more likely that "damages" in $\$ 404(\mathrm{~b})$ refers only to actual damages, for $\$ 504$ (c) (2) states:

In a case where the infringer sustains the burden of proving that he was not aware and had no reason to believe that his acts constituted an infringement of copyright, the court in its discretion may reduce the award of statutory damages to a sum of not less than $\$ 100$.

This statement implies that statutory damages are proper even in cases of innocent infringement.

36 H.R. 4347, 89th Cong., 1st Sess. §411(2) (1965).

37 H.R. 4347, 89th Cong., 1st Sess. § 404(b) (1965). 
limiting the liability of an innocent infringer. These interests are best reconciled by expanding section 21 of the present copyright statute ${ }^{38}$ to include innocent infringement of subsisting copyrights. Thus, in the situation where a subsisting copyright is infringed by the copying of an uncopyrighted derivative work, the original copyright would not be forfeited, but the copyright proprietor would be remitted to limited remedies against the infringer. Such an approach has been included in the proposed copyright revision to mitigate the harsh penalties that presently obtain for failure to include notice of copyright, and thus it would be consistent with the new statute. To remedy the failure of the present statute and the proposed revision to deal specifically with the problems of subsisting copyrights, section 404 of the proposed statute should be amended to provide: (1) publication of an uncopyrighted derivative work does not affect the validity of any subsisting copyrights; and (2) one who innocently infringes a subsisting copyright by copying a derivative work shall be considered an innocent infringer within the terms of proposed section 404(b).

If these suggested amendments are included in the proposed revision, the subsisting copyright proprietor's rights would depend upon the infringer's knowledge of the subsisting copyright. Thus, though the derivative work may not be protected, the subsisting copyright owner will have an independent cause of action against the copier. In most cases this cause of action will be limited to the remedies for innocent infringement since it is unlikely that an innocent infringer of a derivative work will have notice of the subsisting copyright. ${ }^{39}$

Giving the subsisting copyright owner an independent cause of action creates the possibility that the copying of a derivative work will infringe both the derivative and subsisting copyrights. ${ }^{40}$ The extent of the copier's liability will depend upon whether he can prove that he was an innocent infringer with respect to one or both of the copyrights. In those situations where the infringement is not innocent, there is no problem in fashioning remedies, for each copyright owner will prosecute his independent cause of action. ${ }^{41}$ However, when both of the copyrights are innocently infringed, two important questions are posed: are both copyright owners entitled to the maximum statutory damages provided by section 404 (b) ; and who bears the cost of reimbursing the copier for his expenses or, alternatively, who receives the

3817 U.S.C. $\$ 21$ (1964).

39 Both Bentley and Grove Press contained notices indicating a subsisting copyright. See note 21 supra. Under the proposed revision if a derivative work is registered, the registration should indicate all subsisting copyrights. H.R. 4347, 89th Cong., 1st Sess. \$ 408(9) (1965). If requested, the Copyright Office would furnish this information. H.R. 4347, 89th Cong., 1st Sess. § 705 (c) (1965).

40 See Wihtol v. Crow, 309 F.2d 777, 781 (8th Cir. 1962).

41 The copyright proprietor whose material was innocently infringed will have the choice of requesting the court to grant an injunction or the compulsory license. Where infringement is not innocent the copyright owner can sue for damages under $\S 504$. 
royalties from the compulsory license? With regard to the first question, it might be argued that both copyright proprietors should be able to recover damages up to the statutory maximum since each has an independent cause of action. However, the purpose of section 404(b) is to limit the liability of an innocent infringer; consonant with this purpose the total amount of any recovery from an innocent infringer should be limited to the maximum set in the statute regardless of the number of copyrights infringed. Any such recovery could then be allocated among the various copyright proprietors whose copyrights were infringed.

A more difficult problem arises under section 404 (b) if the court grants an injunction or uses the compulsory licensing procedure. The issue then posed is who should reimburse the copier for his expenses, or who should receive the royalties. In view of the myriad fact patterns which could arise involving infringement of derivative and subsisting copyrights, it would be difficult to state any statutory rule applicable to a majority of cases. ${ }^{42}$ The proposed revision allows the court considerable discretion in fashioning remedies. ${ }^{43}$ Perhaps the best solution would be judicial resolution of these questions according to the equities of the particular situation. However, some guidelines can be suggested. One would be the extent and nature of the injuries produced by the infringement; that is, does the infringement preempt the market for the derivative work or for the original work? A second criterion-which copyright owner has the right to license the copier to produce the infringing work-could be employed in combination with the first. Both of these considerations are designed to determine which party has the greater interest in halting the infringement, and then designating that copyright owner either to reimburse the copier for his expenses or to receive the royalties depending upon the remedy the court chooses.

All of the suggested changes are intended to remedy the failure of the proposed statute to deal with the problem of subsisting copyrights. Their adoption will clarify an inadequately charted area of the law and rectify an unfortunate omission in the proposed statute.

42 The fact situations could vary depending upon whether the infringing work was a copy of the derivative work, or another version based upon the derivative work, such as a play developed from a translation, which infringes both the derivative and the underlying work. Other factors would be the extent of the derivative copyright owner's license, and whether the subsisting copyright owner was receiving a percentage from the derivative owner's sales or whether he sold his rights for a lump sum.

43 See H.R. 4347, 89th Cong., 1st Sess. \$§ 404(b), 502(a), 504(c) (1965). The court has similar discretion under present law. See 17 U.S.C. $\$ \$ 21,101$ (b) (1964). 